\title{
Studi Pendahuluan Pengendapan Cerium, Lanthanum, dan Neodymium dari Larutan Klorida Menggunakan Sodium Karbonat pada Pengolahan Monasit Bangka
}

\section{Preliminary Study of Cerium, Lanthanum, and Neodymium Precipitation from Chloride Solution Using Sodium Carbonate in the Processing of Bangka Monazite}

\author{
Kurnia Trinopiawan $^{1 *}$, Venny Nur Avifa ${ }^{2}$, Yarianto Sugeng Budi Susilo ${ }^{1}$, Ersina Rakhma ${ }^{1}$, \\ Yayat Iman Supriyatna ${ }^{3}$, Iwan Susanto ${ }^{4}$, Sulaksana Permana ${ }^{5}$, Johny Wahyuadi Soedarsono ${ }^{5}$ \\ ${ }^{1}$ Pusat Teknologi Bahan Galian Nuklir - BATAN, \\ Jl. Lebak Bulus Raya No. 9 Pasar Jumat, Jakarta, Indonesia, 12440 \\ ${ }^{2}$ Departemen Kimia, Fakultas Sains, Institut Teknologi Sepuluh Nopember Surabaya, \\ J1. Teknik Mesin No.175, Keputih, Sukolilo, Surabaya, Jawa Timur, Indonesia, 60115 \\ ${ }^{3}$ Balai Penelitian Teknologi Mineral - LIPI, \\ J1. Ir. Sutami Km. 15 Tanjung Bintang, Lampung, Indonesia, 35361 \\ ${ }^{4}$ Program Studi Teknik Mesin, Politeknik Negeri Jakarta, \\ J1. Prof. Dr. G. A. Siwabessy, Kampus Universitas Indonesia, Depok, Jawa Barat, Indonesia 16425 \\ ${ }^{5}$ Departemen Teknik Metalurgi dan Material, Fakultas Teknik, Universitas Indonesia, \\ Kampus Universitas Indonesia, Depok, Jawa Barat, Indonesia, 16424 \\ *E-mail: kurnia.t@batan.go.id
}

Naskah diterima: 3 Mei 2020, direvisi: 6 Mei 2020, disetujui: 12 Mei 2020

DOI: 10.17146/eksplorium.2020.41.1.5871

\begin{abstract}
ABSTRAK
Mineral monasit sebagai mineral ikutan penambangan timah di Kepulauan Bangka Belitung mengandung unsur tanah jarang ringan, diantaranya Cerium (Ce), Lanthanum (La), dan Neodymium (Nd). Tujuan penelitian ini adalah untuk memperoleh konsentrat unsur tanah jarang karbonat melalui proses pengendapan dengan sodium karbonat $\left(\mathrm{Na}_{2} \mathrm{CO}_{3}\right)$, serta menentukan pengaruh konsentrasi dan volume $\mathrm{Na}_{2} \mathrm{CO}_{3}$ terhadap recovery pengendapan $\mathrm{Ce}$, La, dan Nd. Persiapan umpan dilakukan dengan mengikuti rute proses pengolahan monasit menggunakan metode basa meliputi tahapan dekomposisi, pelarutan, dan pengendapan unsur radioaktif. Recovery pengendapan tertinggi untuk $\mathrm{Ce}$, La, dan $\mathrm{Nd}$ yaitu sebesar $10,84 \%, 7,81 \%$, dan 2,68\% pada penggunaan $\mathrm{Na}_{2} \mathrm{CO}_{3}$ dengan konsentrasi $30 \%$ wt dan volume $55 \mathrm{~mL}$.
\end{abstract}

Kata kunci: monasit, pengendapan, $\mathrm{Ce}, \mathrm{La}, \mathrm{Nd}, \mathrm{Na}_{2} \mathrm{CO}_{3}$

\begin{abstract}
Monazite mineral as associated mineral of tin mining in Bangka Belitung Islands contains light rare earth elements like Cerium (Ce), Lanthanum (La), and Neodymium (Nd). The objective of this study is to obtain the concentrates of rare earth carbonate through the precipitation process with sodium carbonate $\left(\mathrm{Na}_{2} \mathrm{CO}_{3}\right)$ and determine the effect of concentration and volume of $\mathrm{Na}_{2} \mathrm{CO}_{3}$ on the precipitation recovery of Ce, $\mathrm{La}$, and $\mathrm{Nd}$. The preparation of the feed solution was carried out by following the monazite processing route using the alkali method includes the stages of decomposition, dissolution, and precipitation of radioactive elements. The highest precipitation recovery for $\mathrm{Ce}, \mathrm{La}$, and $\mathrm{Nd}$ are $10.84 \%, 7.81 \%$, and $2.68 \%$ respectively in the use of $\mathrm{Na}_{2} \mathrm{CO}_{3}$ with a concentration of $30 \%$ wt and a volume of $55 \mathrm{~mL}$.
\end{abstract}

Keywords: monazite, precipitation, $\mathrm{Ce}, \mathrm{La}, \mathrm{Nd}, \mathrm{Na}_{2} \mathrm{CO}_{3}$ 


\section{PENDAHULUAN}

Cerium (Ce), Lanthanum (La), dan Neodymium $(\mathrm{Nd})$ merupakan unsur tanah jarang ringan yang terkandung dalam mineral monasit. Saat ini, produksi unsur tanah jarang dunia didominasi oleh Cina yang memiliki sumber daya unsur tanah jarang dalam berbagai mineral seperti bastnasit dan monasit [1, 2]. Di Indonesia, monasit dapat diperoleh sebagai mineral ikutan dalam penambangan timah khususnya di Kepulauan Bangka Belitung [3]. Keberadaan unsur radioaktif seperti uranium (U) dan torium (Th) dalam monasit perlu mendapatkan perhatian dalam pengelolaannya. Pengelolaan ini dilakukan untuk mendapatkan nilai tambah melalui ekstraksi logam-logam berharga didalam monasit. Selain itu, risiko paparan radiasi dapat menimbulkan potensi bahaya bagi lingkungan sekitar lokasi penambangan [4].

Unsur tanah jarang atau Rare-earth Element (RE) memiliki karakteristik unggul dalam pemanfaatannya sebagai material maju, diantaranya penggunaan dalam industri komunikasi, elektronika, keramik, dan paduan logam [5]. Tingginya nilai ekonomi dan risiko ketersediaannya yang cukup tinggi menjadikan $\mathrm{Ce}, \mathrm{La}$, dan $\mathrm{Nd}$, serta unsur $\mathrm{RE}$ lainnya dikategorikan sebagai material kritis [6-10]. Konsentrat logam tanah jarang dapat diproduksi dalam bentuk senyawa hidroksida, oksalat, ataupun karbonat. Konsentrat RE karbonat merupakan konsentrat RE yang umum diperdagangkan dengan harga berkisar antara 20000-22000 RMB/mt [11]. Penggunaan senyawa karbonat sebagai reagen pengendapan didukung oleh harganya yang relatif murah dibandingkan dengan reagen lain. Proses pemurnian lanjut dari produk RE karbonat yang terbentuk juga akan menjadi lebih mudah [12].

Studi pendahuluan yang dilakukan bertujuan untuk memperoleh konsentrat RE karbonat melalui proses pengendapan dengan menggunakan sodium karbonat $\left(\mathrm{Na}_{2} \mathrm{CO}_{3}\right)$. Selain itu, pengaruh konsentrasi dan volume $\mathrm{Na}_{2} \mathrm{CO}_{3}$ terhadap recovery pengendapan $\mathrm{Ce}, \mathrm{La}$, dan $\mathrm{Nd}$ juga dapat dipelajari.

\section{TEORI}

Monasit dapat dibedakan menjadi beberapa jenis berdasarkan kandungan RE yang dominan. Tiga jenis monasit yang umum ditemui antara lain monasit-(Ce), monasit-(La), dan monasit(Nd) (Tabel 1). Konsentrat monasit yang diperoleh sebagai hasil samping penambangan timah umumnya mengandung 60\% RE oksida yakni terdiri dari oksida $\mathrm{Ce}, \mathrm{La}, \mathrm{Nd}, \mathrm{Sm}, \mathrm{Gd}$, Dy, dan Y [14].

\begin{tabular}{cc}
\multicolumn{2}{c}{ Tabel 1. Nama dan rumus kimia monasit [13]. } \\
\hline Nama & Rumus Kimia \\
\hline Monasit-(Ce) & $(\mathrm{Ce}, \mathrm{La}, \mathrm{Nd}, \mathrm{Th}, \mathrm{Y}) \mathrm{PO}_{4}$ \\
Monasit-(La) & $(\mathrm{La}, \mathrm{Ce}, \mathrm{Nd}) \mathrm{PO}_{4}$ \\
Monasit-(Nd) & $(\mathrm{Nd}, \mathrm{La}, \mathrm{Ce}) \mathrm{PO}_{4}$ \\
\hline
\end{tabular}

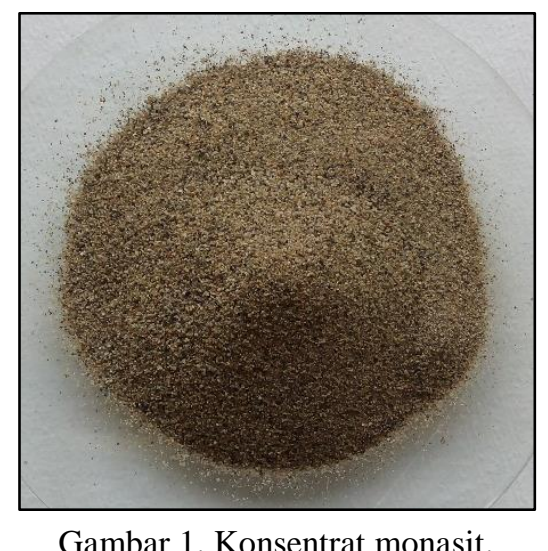

Ekstraksi RE dari monasit dapat dilakukan dengan dua alternatif rute proses, yaitu dijesti asam dan dekomposisi basa $[2,15]$. Pada rute dijesti asam, RE akan terlarut dalam larutan sulfat, kemudian dilanjutkan dengan pemisahan individu unsur-unsur RE. Sementara itu, dalam rute dekomposisi basa, RE akan terlarut dengan asam klorida sehingga diperoleh produk berupa konsentrat RE. Kelebihan rute dekomposisi basa adalah diperolehnya produk samping 
berupa sodium fosfat dengan suhu reaksi yang tidak terlalu tinggi, yaitu $140{ }^{\circ} \mathrm{C}$. Sementara itu, pada rute dijesti asam diperlukan energi yang lebih besar karena reaksi berlangsung pada suhu tinggi (175-200 $\left.{ }^{\circ} \mathrm{C}\right)$ [14].

Penelitian ini merupakan pengembangan dari rute dekomposisi basa untuk memperoleh produk konsentrat RE karbonat. Penelitian sebelumnya menghasilkan produk berupa konsentrat RE hidroksida. Adapun proses pembuatan umpan pada penelitian ini meliputi tahapan: dekomposisi monasit dengan $\mathrm{NaOH}$, pelarutan $\mathrm{RE}$ dengan $\mathrm{HCl}$, dan pengendapan unsur radioaktif dengan $\mathrm{NH}_{4} \mathrm{OH}$.

Dekomposisi adalah tahapan proses untuk mengkonversi RE.PO ${ }_{4}$ menjadi $\mathrm{RE}(\mathrm{OH})_{3}$ yang mudah larut dalam asam klorida. Melalui proses ini diperoleh produk samping berupa sodium fosfat $\left(\mathrm{Na}_{3} \mathrm{PO}_{4}\right)$. Persamaan reaksi dekomposisi adalah sebagai berikut $[14,16,17]$ :

$$
\begin{aligned}
& \text { RE.PO } \mathrm{PO}_{4}+3 \mathrm{NaOH} \rightarrow \mathrm{RE}(\mathrm{OH})_{3}+\mathrm{Na}_{3} \mathrm{PO}_{4} \\
& \text {Th} . P O_{4}+3 \mathrm{NaOH} \rightarrow \mathrm{Th}(\mathrm{OH})_{4}+\mathrm{Na}_{3} \mathrm{PO}_{4}
\end{aligned}
$$

Residu dekomposisi yang merupakan konsentrat $\mathrm{RE}(\mathrm{OH})_{3}$ dilarutkan dengan $\mathrm{HCl}$ untuk memperoleh larutan RE klorida, sesuai dengan persamaan reaksi [16]:

$$
\begin{aligned}
& \mathrm{RE}(\mathrm{OH})_{3}+3 \mathrm{HCl} \rightarrow \mathrm{RECl}_{3}+3 \mathrm{H}_{2} \mathrm{O} \\
& \mathrm{Th}(\mathrm{OH})_{4}+4 \mathrm{HCl}=\mathrm{ThCl}_{4}+4 \mathrm{H}_{2} \mathrm{O}
\end{aligned}
$$

Larutan klorida ditambahkan ammonium hidroksida untuk mengendapkan unsur radioaktif yang ikut terlarut. Persamaan reaksi pengendapan tersebut adalah sebagai berikut [16]:

$$
\mathrm{ThCl}_{4}+4 \mathrm{NH}_{4} \mathrm{OH}=\mathrm{Th}(\mathrm{OH})_{4}+4 \mathrm{NH}_{4} \mathrm{Cl}
$$

Konsentrat RE dari larutan klorida dapat diendapkan menjadi senyawa karbonat pada $\mathrm{pH}$ tinggi. Persamaan reaksi pengendapan RE karbonat adalah sebagai berikut [12]:

$$
2 \mathrm{RE}^{3+}+3 \mathrm{CO}_{3}{ }^{2-}=\mathrm{RE}_{2}\left(\mathrm{CO}_{3}\right)_{3}
$$

Ion karbonat dalam larutan dapat berupa $\mathrm{CO}_{3}{ }^{2-}$ dan $\mathrm{HCO}_{3}{ }^{-}$tergantung pada $\mathrm{pH}$ larutan. Apabila larutan umpan pengendapan memiliki $\mathrm{pH}$ lebih rendah dari 6 dengan nilai $\mathrm{pKa} \mathrm{HCO}_{3}{ }^{-} / \mathrm{CO}_{3}{ }^{2-}$ sebesar 10,34 maka spesi kimia yang stabil adalah $\mathrm{H}_{2} \mathrm{CO}_{3}$ sehingga persamaan reaksi menjadi [12]:

$$
2 \mathrm{RECl}^{2+}+3 \mathrm{H}_{2} \mathrm{CO}_{3}=\mathrm{RE}_{2}\left(\mathrm{CO}_{3}\right)_{3}+2 \mathrm{Cl}^{-}+6 \mathrm{H}^{+}(7)
$$

Pada persamaan (7), energi bebas Gibbs untuk pembentukan senyawa $\mathrm{Ce}$ karbonat adalah -761,4 $\mathrm{kCal} / \mathrm{mol}$, sementara untuk pembentukan senyawa $\mathrm{La}$ dan $\mathrm{Nd}$ karbonat masing-masing sebesar -768,5 kCal/mol dan $-761,6 \mathrm{kCal} / \mathrm{mol}$ [12]. Hal ini menunjukkan bahwa reaksi pengendapan ketiga unsur tersebut dengan reagen karbonat dapat berlangsung secara spontan.

\section{METODOLOGI}

Bahan baku menggunakan konsentrat monasit yang berasal dari penambangan timah di Provinsi Kepulauan Bangka Belitung. Analisis komposisi unsur dalam monasit dilakukan dengan alat X-Ray Fluorescence (XRF) Spectro Xepos HE. Prosedur percobaan dapat dilihat pada Gambar 2.

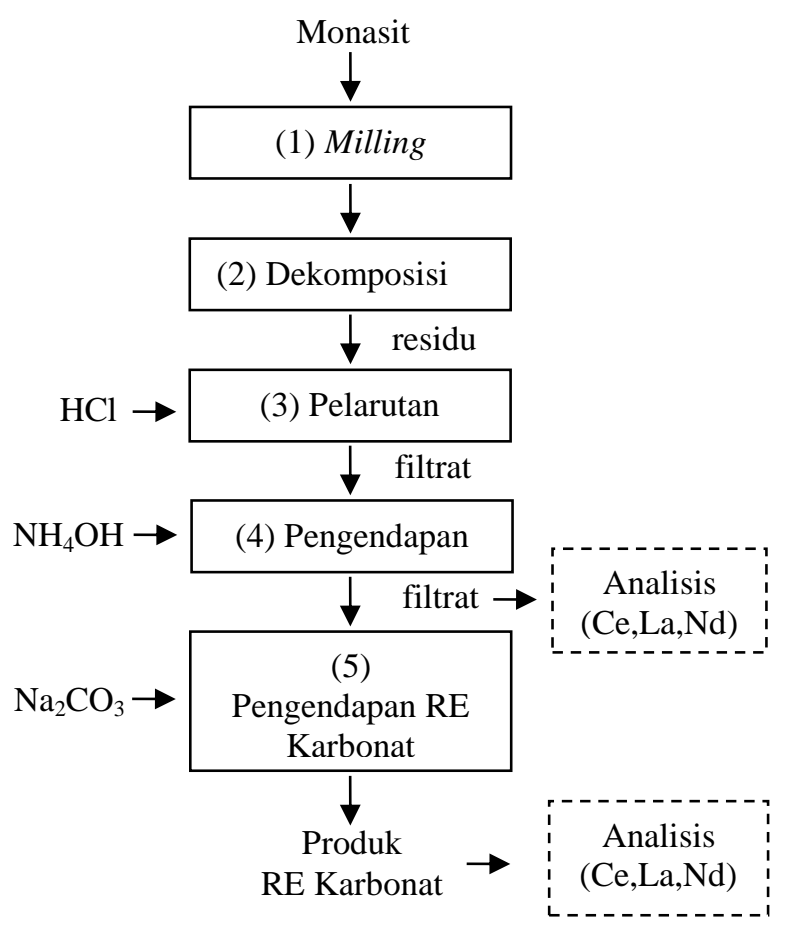

Gambar 2. Diagram alir prosedur percobaan. 
Pembuatan larutan umpan merupakan tahapan awal yang terdiri dari 4 proses kegiatan (Gambar 2). Proses pertama (1) adalah menghaluskan monasit dengan menggunakan ball mill. Selanjutnya proses kedua (2), monasit yang telah halus dimasukkan ke dalam gelas beaker dan dicampur dengan $\mathrm{NaOH}$ yang telah dilarutkan dalam air. Slurry diaduk dengan pengaduk digital IKA RW-20 kemudian dipanaskan di atas hot plate Thermolyne 4800. Selanjutnya, slurry difiltrasi dengan filter vakum. Pada proses ketiga (3), residu yang diperoleh kemudian dilarutkan dengan $\mathrm{HCl}$ menggunakan gelas beaker dengan peralatan yang sama seperti proses sebelumnya hingga diperoleh larutan klorida yang mengandung unsur tanah jarang. Proses keempat (4), larutan klorida ditambahkan $\mathrm{NH}_{4} \mathrm{OH}$ untuk mengendapkan unsur radioaktif. Endapan yang terbentuk dipisahkan dari filtratnya. Larutan klorida yang diperoleh kemudian digunakan sebagai larutan umpan pada percobaan pengendapan. Komposisi unsur pada larutan umpan dianalisis menggunakan metode Inductively Coupled Plasma-Optical Emission Spectrometry (ICP-OES) pada alat PerkinElmer ICP-OES Optima 8300.

Proses kelima (5) adalah percobaan pengendapan untuk mendapatkan variasi konsentrasi dan volume larutan $\mathrm{Na}_{2} \mathrm{CO}_{3}$. Larutan umpan sebanyak $50 \mathrm{~mL}$ diletakkan ke dalam gelas beaker. Larutan umpan diteteskan larutan $\mathrm{Na}_{2} \mathrm{CO}_{3}$ dengan variasi konsentrasi 10 $30 \%$ wt hingga $\mathrm{pH}$ mencapai 9 dan terus diaduk dengan magnetic stirrer. Setelah $\mathrm{pH}$ mencapai 9, maka proses penambahan larutan $\mathrm{Na}_{2} \mathrm{CO}_{3}$ dihentikan dan pengadukan dilanjutkan selama 30 menit. Setelah 30 menit larutan hasil pengendapan disaring. Endapan yang dihasilkan dan diindikasi sebagai RE karbonat kemudian dikeringkan dengan oven pada suhu $105^{\circ} \mathrm{C}$. Endapan dikarakterisasi menggunakan alat $X$ Ray Fluorescence (XRF) Spectro Xepos HE.
Data yang diperoleh digunakan untuk perhitungan recovery pengendapan sesuai dengan persamaan berikut:

$$
\text { Recovery }(\%)=\frac{\mathrm{M}_{\mathrm{e}}}{\mathrm{M}_{\mathrm{u}}} x 100 \%
$$

Nilai $\mathrm{M}_{\mathrm{e}}$ adalah massa unsur dalam endapan, dan $\mathbf{M}_{\mathbf{u}}$ adalah massa unsur dalam larutan umpan.

Setelah didapatkan konsentrasi larutan $\mathrm{Na}_{2} \mathrm{CO}_{3}$ yang memberikan recovery pengendapan tertinggi, percobaan pengendapan dilanjutkan dengan variasi volume larutan $\mathrm{Na}_{2} \mathrm{CO}_{3}$ dalam rentang $10 \mathrm{~mL}$ hingga $55 \mathrm{~mL}$. Endapan yang diperoleh dikeringkan dan dikarakterisasi menggunakan XRF.

\section{HASIL DAN PEMBAHASAN}

\section{Karakterisasi Bahan Baku dan Larutan Umpan}

Karakterisasi bahan baku monasit menggunakan XRF menunjukkan bahwa kandungan unsur $\mathrm{RE}$ antara lain $\mathrm{La}, \mathrm{Ce}, \mathrm{Nd}$ cukup tinggi. Unsur RE yang dominan dalam monasit adalah Ce dengan konsentrasi sebesar $18,27 \%$ (Tabel 2). Hal ini menunjukkan monasit yang digunakan dalam penelitian ini merupakan tipe monasit-(Ce).

\begin{tabular}{ccccc}
\multicolumn{4}{c}{ Tabel 2. Hasil analisis monasit dengan XRF } \\
\hline La & $\mathrm{Ce}$ & $\mathrm{Nd}$ & $\mathrm{Th}$ & Unsur lain \\
$(\%)$ & $(\%)$ & $(\%)$ & $(\%)$ & $(\%)$ \\
\hline 11,34 & 18,27 & 8,64 & 6,47 & 57,49 \\
\hline
\end{tabular}

Hasil analisis ICP-OES pada larutan umpan menunjukkan bahwa larutan umpan masih mengandung RE hingga 1,012\%. Cerium merupakan unsur dengan kadar tertinggi, diikuti La dan Nd. Pola ini konsisten terhadap nilai kadar awal monasit saat masih menjadi bahan baku (Tabel 2). Selain itu, larutan umpan juga mengandung beberapa unsur pengotor yang dominan, diantaranya Fe, Al, dan P hingga 169 ppm (Tabel 3). 
Table 3.Komposisi larutan umpan pengendapan.

\begin{tabular}{cccccc}
\hline $\begin{array}{c}\mathrm{La} \\
(\%)\end{array}$ & $\begin{array}{c}\mathrm{Ce} \\
(\%)\end{array}$ & $\begin{array}{c}\mathrm{Nd} \\
(\%)\end{array}$ & $\begin{array}{c}\mathrm{Fe} \\
(\mathrm{ppm})\end{array}$ & $\begin{array}{c}\mathrm{Al} \\
(\mathrm{ppm})\end{array}$ & $\begin{array}{c}\mathrm{P} \\
(\mathrm{ppm})\end{array}$ \\
\hline 0,628 & 1,012 & 0,519 & 169 & 161 & 72 \\
\hline
\end{tabular}

\section{Pengaruh Konsentrasi Sodium Karbonat Terhadap Recovery Pengendapan.}

Pengendapan $\mathrm{Ce}$, La, dan $\mathrm{Nd}$ dari larutan klorida dengan $\mathrm{Na}_{2} \mathrm{CO}_{3}$ dilakukan pada variasi konsentrasi $\mathrm{Na}_{2} \mathrm{CO}_{3} 10,15,20,25$, dan $30 \%$ wt (Gambar 3-5). Recovery $\mathrm{Ce}$ maupun pengotornya meningkat seiring dengan bertambahnya konsentrasi $\mathrm{Na}_{2} \mathrm{CO}_{3}$. Recovery Ce tertinggi, yaitu sebesar 3,83\% diperoleh pada konsentrasi $\mathrm{Na}_{2} \mathrm{CO}_{3} 30 \%$ wt, sementara $\mathrm{Fe}, \mathrm{Al}$, serta $\mathrm{P}$ yang ikut mengendap sebesar $0,19 \%$, 0,34\%, dan 0,46\% (Gambar 3). Selektivitas presipitasi Ce meningkat dengan bertambahnya konsentrasi $\mathrm{Na}_{2} \mathrm{CO}_{3}$ karena peningkatan konsentrasi tidak memberikan kenaikan recovery unsur-unsur pengotor $\mathrm{Fe}, \mathrm{Al}$, dan P. Kenaikan konsentrasi $\mathrm{Na}_{2} \mathrm{CO}_{3}$ dari $10 \%$ ke 30\% wt memberikan kenaikan recovery $\mathrm{Ce}$ sebesar $0,24 \%$, sedangkan untuk Fe, $\mathrm{Al}$, dan $\mathrm{P}$ sebesar $0,03 \%, 0,18 \%$, dan $0,06 \%$.

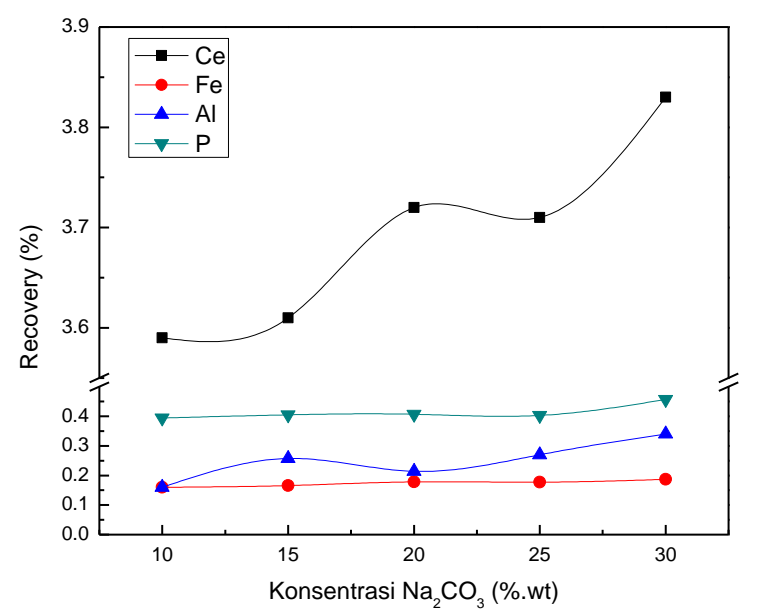

Gambar 3. Recovery Ce pada variasi konsentrasi sodium karbonat.

Recovery La pada variasi konsentrasi $\mathrm{Na}_{2} \mathrm{CO}_{3}$ memiliki tren yang sama dengan $\mathrm{Ce}$ maupun pengotornya. Recovery La meningkat hingga diperoleh recovery sebesar 2,35\% pada konsentrasi $\mathrm{Na}_{2} \mathrm{CO}_{3} 30 \%$ wt (Gambar 4). Hasil percobaan menunjukkan bahwa presipitasi menggunakan $\mathrm{Na}_{2} \mathrm{CO}_{3}$ tidak cukup selektif untuk mendapatkan endapan La dengan sedikit pengotor $\mathrm{Fe}, \mathrm{Al}$, dan $\mathrm{P}$. Pada rentang konsentrasi $10 \%$ hingga $30 \%$ wt, kenaikan recovery La sebesar $0,06 \%$ sedangkan kenaikan recovery $\mathrm{Fe}, \mathrm{Al}$, dan $\mathrm{P}$ sebesar $0,03 \%, 0,18 \%$, dan $0,06 \%$.

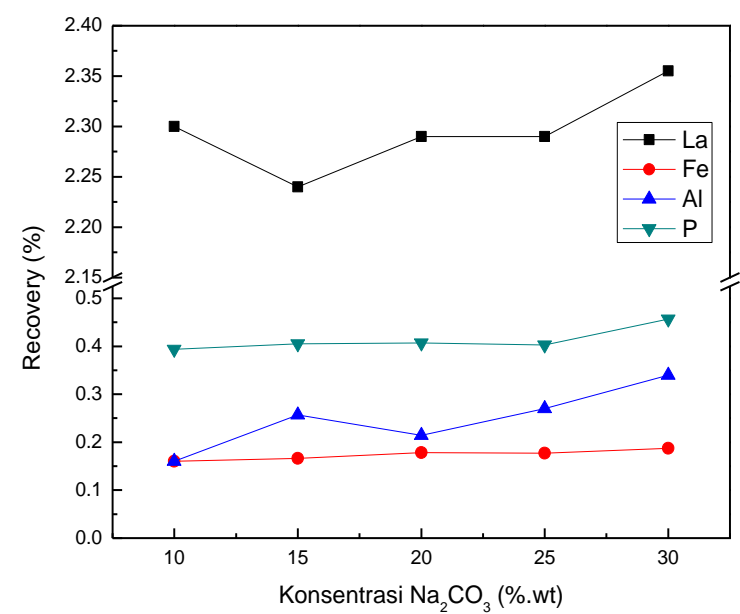

Gambar 4. Recovery La pada variasi konsentrasi sodium karbonat.

Sama halnya dengan $\mathrm{Ce}$ dan $\mathrm{La}$, recovery $\mathrm{Nd}$ semakin tinggi pada konsentrasi $\mathrm{Na}_{2} \mathrm{CO}_{3}$ yang tinggi (Gambar 5). Recovery $\mathrm{Nd}$ tertinggi diperoleh pada konsentrasi $30 \%$ wt yaitu sebesar 1,01\%. Presipitasi menggunakan $\mathrm{Na}_{2} \mathrm{CO}_{3}$ cukup selektif untuk $\mathrm{Nd}$ dengan kenaikan recovery mencapai $0,14 \%$ dan kenaikan recovery pengotor yang lebih rendah, yaitu $\mathrm{Fe} 0,03 \%, \mathrm{Al} 0,18 \%$, dan P 0,06\%.

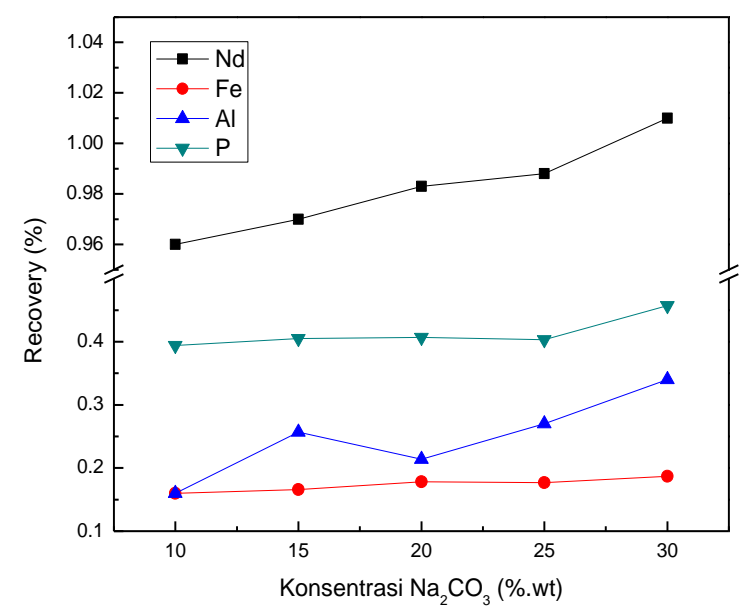

Gambar 5. Recovery Nd pada variasi konsentrasi sodium karbonat 
Tren recovery $\mathrm{Ce}$, $\mathrm{La}$, dan $\mathrm{Nd}$ pada pengendapan menggunakan larutan $\mathrm{Na}_{2} \mathrm{CO}_{3}$ memiliki kemiripan. Peningkatan konsentrasi $\mathrm{Na}_{2} \mathrm{CO}_{3}$ meningkatkan recovery $\mathrm{Ce}$, La, dan $\mathrm{Nd}$. Hal ini disebabkan ketiga unsur tersebut merupakan unsur lantanida yang memiliki kemiripan sifat fisika maupun kimia [1, 18]. Dari hasil percobaan dengan rentang konsentrasi $\mathrm{Na}_{2} \mathrm{CO}_{3} \quad 10 \%$ hingga $30 \%$ wt, recovery $\mathrm{Ce}, \mathrm{La}$, dan $\mathrm{Nd}$ masih terus meningkat dan belum mencapai keadaan setimbang sehingga perlu dilakukan studi lanjut dengan konsentrasi $\mathrm{Na}_{2} \mathrm{CO}_{3}$ yang lebih tinggi. Peningkatan recovery pengendapan yang berbanding lurus dengan kenaikan konsentrasi juga terjadi pada proses pengendapan unsur RE dari larutan klorida menggunakan $\mathrm{NaOH}$ [19].

\section{Pengaruh Volume Sodium Karbonat Terhadap Recovery Pengendapan.}

Pengendapan $\mathrm{Ce}$, La, dan $\mathrm{Nd}$ dari larutan klorida dengan $\mathrm{Na}_{2} \mathrm{CO}_{3}$ dilakukan pada variasi volume sodium karbonat (30\% wt) sebesar 10 , 20, 30, 40, 50, $55 \mathrm{~mL}$ (Gambar 6-8). Pengendapan Ce pada volume $\mathrm{Na}_{2} \mathrm{CO}_{3} 10 \mathrm{~mL}$ hingga $40 \mathrm{~mL}$ tidak menunjukkan perubahan recovery Ce yang signifikan (Gambar 6). Ketika volumenya ditambah menjadi $50 \mathrm{~mL}$ terjadi peningkatan recovery $\mathrm{Ce}$ yang tinggi. Recovery tertinggi sebesar $10,4 \%$ diperoleh pada penambahan volume $\mathrm{Na}_{2} \mathrm{CO}_{3}$ sebesar $55 \mathrm{~mL}$. Kenaikan recovery pengotor signifikan pada penggunaan $\mathrm{Na}_{2} \mathrm{CO}_{3}$ dari $40 \mathrm{~mL}$ ke $50 \mathrm{~mL}$ pada unsur $\mathrm{Fe}$ dan $\mathrm{P}$, namun recovery $\mathrm{P}$ mengalami kenaikan signifikan pada perubahan volume $\mathrm{Na}_{2} \mathrm{CO}_{3}$ dari $50 \mathrm{~mL}$ menjadi $55 \mathrm{~mL}$. Dengan demikian, pengendapan Ce pada variasi volume $\mathrm{Na}_{2} \mathrm{CO}_{3}$ tidak cukup selektif.

Fenomena yang terjadi pada pengendapan La mirip dengan pengendapan $\mathrm{Ce}$, yaitu recovery La pada volume $\mathrm{Na}_{2} \mathrm{CO}_{3} 10 \mathrm{~mL}$ hingga $40 \mathrm{~mL}$ cenderung konstan dan naik secara signifikan pada penambahan $\mathrm{Na}_{2} \mathrm{CO}_{3} 50$
$\mathrm{mL}$ (Gambar 7). Recovery La tertinggi diperoleh pada volume $\mathrm{Na}_{2} \mathrm{CO}_{3} 55 \mathrm{ml}$ yaitu sebesar 7,81\%. Pada perubahan volume $\mathrm{Na}_{2} \mathrm{CO}_{3}$ $40 \mathrm{~mL}$ menjadi $50 \mathrm{~mL}$, terjadi kenaikan recovery La sebesar 5,01\%. Dari ketiga pengotor, dapat diamati pada rentang tersebut hanya $\mathrm{Al}$ yang mengalami penurunan recovery sedangkan $\mathrm{Fe}$ dan $\mathrm{P}$ mengalami kenaikan recovery.

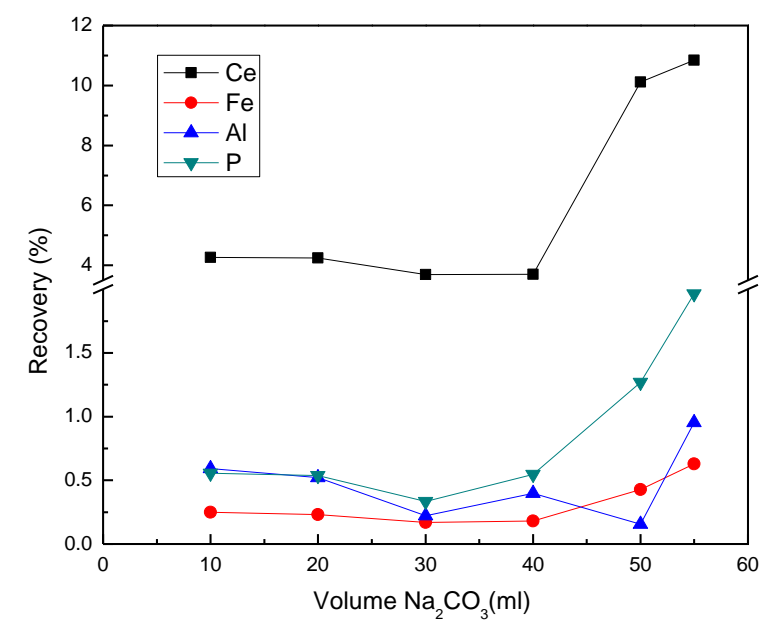

Gambar 6. Recovery Ce pada variasi volume sodium karbonat.

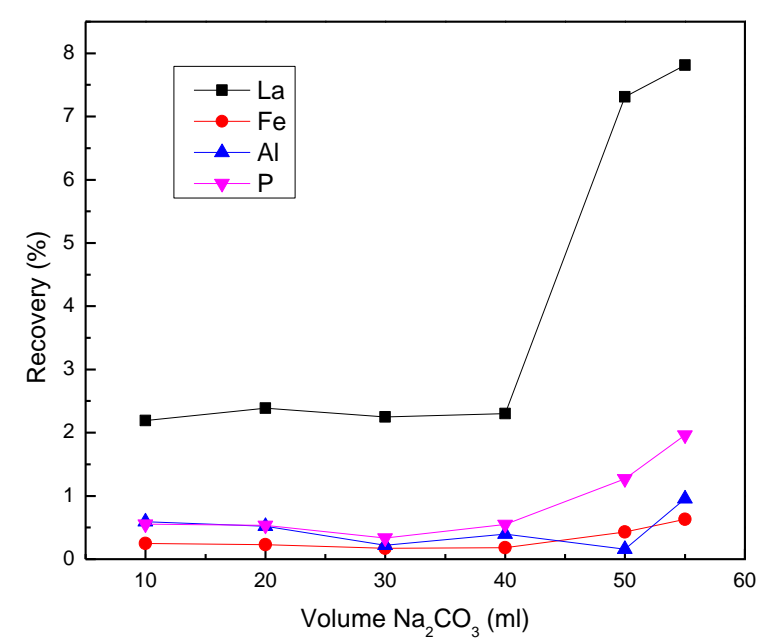

Gambar 7. Recovery La pada variasi volume sodium karbonat.

Berbeda dengan recovery $\mathrm{Ce}$ dan $\mathrm{La}$ yang cenderung konstan pada penambahan $\mathrm{Na}_{2} \mathrm{CO}_{3}$ $10 \mathrm{~mL}$ hingga $40 \mathrm{~mL}$, recovery $\mathrm{Nd}$ mengalami penurunan dari 1,31\% menjadi 1\% (Gambar 8). Ketika volume $\mathrm{Na}_{2} \mathrm{CO}_{3}$ ditingkatkan menjadi 50 $\mathrm{ml}$ terjadi peningkatan secara signifikan sebesar 
1,5\%. Recovery Nd tertinggi sebesar 2,68\% diperoleh pada volume $\mathrm{Na}_{2} \mathrm{CO}_{3} 55 \mathrm{~mL}$.

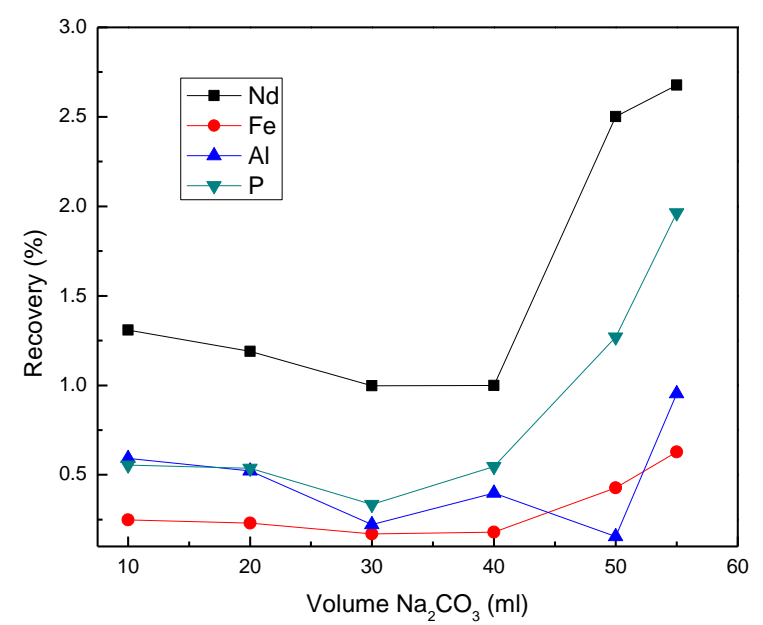

Gambar 8. Recovery $\mathrm{Nd}$ pada variasi volume sodium karbonat.

Sama halnya dengan percobaan menggunakan variasi konsentrasi $\mathrm{Na}_{2} \mathrm{CO}_{3}$, percobaan menggunakan variasi volume $\mathrm{Na}_{2} \mathrm{CO}_{3}$ pada rentang $10 \mathrm{~mL}$ hingga $55 \mathrm{~mL}$ menunjukkan recovery $\mathrm{Ce}, \mathrm{La}$, dan $\mathrm{Nd}$ masih terus meningkat dan belum mencapai keadaan setimbang sehingga perlu dilakukan studi lanjut dengan volume $\mathrm{Na}_{2} \mathrm{CO}_{3}$ yang lebih dari $55 \mathrm{ml}$. Recovery pengendapan yang meningkat seiring dengan penambahan volume reagen pengendap ini polanya mirip dengan hasil penelitian pengendapan menggunakan asam oksalat [18]. Proses penambahan volume reagen akan memperbanyak jumlah ion karbonat dalam sistem sehingga meningkatkan nilai Hasil Kali Kelarutan (Ksp) dan endapan yang terbentuk akan semakin banyak [20].

\section{KESIMPULAN}

Pengendapan $\mathrm{Ce}$, La, dan $\mathrm{Nd}$ dari larutan klorida menggunakan sodium karbonat dapat dilakukan dengan variasi konsentrasi dan volume. Recovery tertinggi dihasilkan untuk $\mathrm{Ce}$, La, dan Nd sebesar 10,84\%, 7,81\%, dan 2,68\% pada konsentrasi sodium karbonat $30 \%$ wt dan volume $55 \mathrm{~mL}$. Pada kondisi tersebut, unsur pengotor $\mathrm{Fe}, \mathrm{Al}$, dan $\mathrm{P}$ ikut mengendap sebesar $6,3 \%, 0.95 \%$, dan $1,96 \%$. Rentang konsentrasi dan volume sodium karbonat yang digunakan belum memperoleh hasil maksimal, sehingga perlu dilakukan penelitian lebih lanjut dengan rentang lebih panjang.

\section{UCAPAN TERIMA KASIH}

Penulis menyampaikan terima kasih kepada PT TIMAH (Persero) Tbk. dalam penyediaan konsentrat monasit untuk digunakan dalam penelitian ini.

\section{DAFTAR PUSTAKA}

[1] C. J Kim, H. S. Yoon, J. Y. Lee,S. D. Kim, S. M. Shin, S. J. Lee, A. R. Joe, S. I. Lee, S. J. Yoo, dan S. H. Kim, "Leaching Kinetics of Lanthanum in Sulfuric Acid from Rare Earth Element (REE) Slag," Hydrometallurgy, vol. 146, pp. 133-137, 2014.

[2] Z. Zhu, Y. Pranolo, dan C. Y. Cheng, "Separation of Uranium And Thorium From Rare Earths for Rare Earth Production - A Review," Mineral Engineering, vol. 77, pp. 185-196, 2015.

[3] K. Szamałek, G. Konopka, K. Zglinicki, dan B. Marciniak-Maliszewska, "New Potential Source of Rare Earth Elements," Gospodarka Surowcami Mineralnymi, vol. 29, no. 4, pp. 59-76, 2013.

[4] E. Prasetyo, Y. I. Supriyatna, F. Bahfie, dan K. Trinopiawan, "Extraction of Thorium from Tin Slag Using Acidic Roasting and Leaching Method," AIP Confrence Proceedings, Vol. 2232, No. 1, 2020.

[5] International Atomic Energy Agency, "Thorium Resources as CO- and By-products of Rare Earth Deposits," IAEA-TECDOC-1892, IAEA, Vienna, 2019.

[6] M. Gergoric, C. Ekberg, B. M. Steenari, dan T. Retegan, "Separation of Heavy Rare-Earth Elements from Light Rare-Earth Elements Via Solvent Extraction from a Neodymium Magnet Leachate and the Effects of Diluents," Sustainable Metallurgy, 2017.

[7] S. Massari dan M. Ruberti, "Rare Earth Elements as Critical Raw Materials: Focus on International Markets and Future Strategies," Resources Policy, vol. 38, no. 1, pp. 36-43, 2013.

[8] E. Allain, N. Kanari, F. Diot, dan J. Yvon, "Development of a Process for the Concentration of the Strategic Tantalum and Niobium Oxides from Tin Slags," Mineral Engineering, vol. 134, pp. 97103, 2019.

[9] A. N. Løvik, C. Hagelüken, dan P. Wäger, "Improving Supply Security of Critical Metals: Current Developments and Research in the EU," Sustainable Materials and Technologies, vol. 15, pp. 9-18, 2018.

[10] S. Zhang, Y. Ding, B. Liu, dan C. C. Chang, "Supply and Demand of Some Critical Metals and 
Present Status of Their Recycling in WEEE," Waste Management, vol. 65, pp. 113-127, 2017.

[11] SMM Information \& Technology Co, Ltd. "Rare Earth Price Chart,China Rare Earth Price TodayShanghai Metals Market." [Online]. Available: https://price.metal.com/Rare-Earth. [Accessed: 02May-2020].

[12] K. N. Han, "Characteristics of Precipitation of Rare Earth Elements with Various Precipitants," Minerals, vol. 10, no. 2, 2020.

[13] C. K. Gupta dan N. Krishnamurthy, "Extractive Metallurgy of Rare Earths," International Material Reviews, vol. 37, no. 1, pp. 197-248, 1992

[14] M. V Purwani dan Suyanti, "Dijesti Monasit Memakai Natrium Hidroksida," Prosiding Pertemuan dan Presentasi Ilmiah-Penelitian Dasar Ilmu Pengetahuan dan Teknologi Nuklir, pp. 36-41, 2014.

[15] S. S. Abhilash, P. Meshram, dan B. D. Pandey, "Metallurgical Processes for the Recovery and Recycling of Lanthanum from Various Resources A Review," Hydrometallurgy, vol. 160, pp. 47-59, 2016
[16] Sumarni, R. Prassanti, K. Trinopiawan, Sumiarti, dan H. L. Nuri, "Penentuan Kondisi Pelarutan Residu dari Hasil Pelarutan Parsial Monasit Bangka," Eksplorium, vol. 32, no. 2, pp. 115-124, 2011.

[17] D. Beltrami, G. J. P. Deblonde, S. Bélair, dan V. Weigel, "Recovery of Yttrium and Lanthanides from Sulfate Solutions with High Concentration of Iron and Low Rare Earth Content," Hydrometallurgy, vol. 157, pp. 356-362, 2015.

[18] H. Güne, H. E. Obuz, dan M. Alkan, "Selective Precipitation of Th and Rare-Earth Elements from $\mathrm{HCl}$ Leach Liquor," Rare Metal Technology 2019, pp. 81-86, 2019.

[19] H. L. Nuri, R. Faizal, W. Sugeng, S. Budi, dan S. Arif, "Pengolahan Monasit Dari Limbah Penambangan Timah: Pemisahan Logam Tanah Jarang (RE) Dari U Dan Th," Prosiding Presentasi Ilmiah Daur Bahan Bakar Nuklir V, pp. 54-60, 2000.

[20] J. S. Schmucker, "More on Geology and Solution Equilibrium," Chemical Education, vol. 59, no. 3, pp. 245-246, 1982 